\title{
PERAN ASOSIASI PENGAJAR HUKUM KETENAGAKERJAAN MEWUJUDKAN MODEL HUBUNGAN INDUSTRIAL YANG HARMONIS DI KAWASAN INDUSTRI KARAWANG
}

\author{
Joko Ismono dan Rihantoro Bayuaji \\ Fakultas Hukum Universitas Wijaya Putra \\ ( jokoismono@uwp.ac.id, bayuaji@uwp.ac.id )
}

\begin{abstract}
Abstrak
Di era disrupsi dewasa ini, perkembangan teknologi informasi dan komunikasi telah menciptakan bukan hanya perubahan yang mendasar dalam hubungan kerja pada umumnya, akan tetapi juga telah melahirkan bentuk-bentuk hubungan kerja baru yang belum diatur dalam peraturan perundang-undangan di bidang ketenagakerjaan. Perselisihan hubungan industrial seringkali berawal dari perbedaan perspektif di antara masyarakat hubungan industrial dalam melihat suatu hubungan kerja. Dalam perspektif pekerja, hubungan kerja dilihat sebagai kewajiban dari pengusaha untuk memenuhi hak-hak normatif pekerja yang telah ditetapkan dalam peraturan perundang-undangan. Sementara dalam perspektif pengusaha, tenaga kerja dilihat sebagai salah satu biaya produksi yang menjadi beban ekonomi bagi perusahaan. Asosiasi pengajar hukum ketenagakerjaan dapat berpartisipasi untuk menjembatani perbedaan perspektif tersebut sebagai suatu bentuk peran serta dalam mewujudkan model masyarakat hubungan industrial yang harmonis. Tujuan dari kegiatan ini adalah pengabdian kepada masyarakat yang dilakukan oleh asosiasi pengajar hukum ketenagakerjaan dalam bentuk kuliah umum, diskusi kelompok, dan pelatihan yang melibatkan serikat pekerja, asosiasi pengusaha, dan dinas tenaga kerja di kawasan industri Karawang Jawa Barat. Lokasi pengabdian pada masyarakat dilakukan di Kabupaten Karawang karena merupakan salah satu kawasan industri terbesar di Indonesia, dimana banyak terjadi perselisihan hubungan industrial.
\end{abstract}

Kata Kunci : asosiasi pengajar, hukum ketenagakerjaan, masyarakat hubungan industrial

\section{A. PENDAHULUAN}

\section{Latar Belakang}

Perkembangan teknologi informasi dan komunikasi yang pesat di era ekonomi digital ini telah membuka lapangan kerja baru, namun di sisi lain menjadi ancaman bagi usaha konvensional. Ekonomi digital memunculkan jenis-jenis pekerjaan yang tidak standar dalam bentuk hubungan kemitraan dengan fleksibilitas yang tinggi. Demikian pula telah terjadi perubahan tuntutan atas keahlian atau skill yang dimiliki oleh tenaga kerja berupa penguasaan terhadap teknologi akan tetapi menjadi lebih fleksibel dimana pekerjaan dapat dilakukan dimana saja dengan bantuan teknologi. Dalam upaya mengatasi permasalahan ketenagakerjaan, pemerintah perlu melakukan penyesuaian terhadap kebijakan di bidang hubungan industrial.

Adapun yang menjadi rasionalisasi dari kegiatan pengabdian kepada masyarakat ini adalah belum adanya pemahaman yang komprehensif di kalangan pekerja, serikat pekerja, perusahaan, dan organisasi pengusaha mengenai dasar-dasar hukum ketenagakerjaan, hubungan kerja, hubungan industrial, hak-hak 
normatif ketenagakerjaan, dan penyelesaian perselisihan hubungan industrial. Pemahaman yang komprehensif mengenai dasar-dasar hukum ketenagakerjaan diperlukan sebagai landasan dalam mewujudkan hubungan industrial yang harmonis di antara pekerja dan pengusaha.

Urgensi dari kegiatan pengabdian terhadap masyarakat ini adalah semakin meningkatnya kualitas dan kuantitas perselisihan hubungan industrial yang terjadi di kawasan industri Karawang. Perselisihan yang sering terjadi adalah perselisihan pemutusan hubungan kerja, perselisihan hak mengenai pengupahan, pelaksanaan upah minimum (UMK), tunjangan hari raya (THR), jam kerja, jaminan sosial tenaga kerja, hak berserikat bagi pekerja, hak berunding secara kolektif, serta keselamatan dan kesehatan kerja (K3).

Karawang merupakan salah satu kota di Jawa Barat yang sebelumnya masih menjadi kabupaten ini merupakan kota yang berbatasan langsung dengan Bekasi, Bogor, dan tidak jauh dari Jakarta. Kota Karawang memiliki luas sekitar 1.737,30 Km2. Dari data yang dihimpun dari Dinas Tenaga Kerja dan Transmigrasi (Disnakertrans) Karawang hingga tahun 2019 terdapat 13.756.358 hektar luas tanah yang diperuntukkan sebagai lahan industri. Pada awal perkembangannya Karawang dikenal sebagai daerah lumbung padi dan sebagian besar penduduk bermata pencaharian sebagai petani. Namun sekarang Karawang lebih dikenal sebagai salah satu kota industri terbesar di Indonesia. Tercatat jumlah pabrik di Karawang sebanyak 1.763 pabrik dengan rincian 1065 penanaman modal dalam negeri (PMDN) dan sebanyak 698 pabrik penanaman modal asing (PMA).

\section{Tujuan dan Manfaat Kegiatan}

Tujuan dari kegiatan pengabdian kepada masyarakat ini adalah sebagai berikut :

1. Memberikan pengetahuan mengenai dasar-dasar hukum ketenagakerjaan kepada pekerja, serikat pekerja, perusahaan, serta asosiasi pengusaha.
2. Merancang pembentukan lembaga kerjasama bipartit dan tripartit dengan tujuan untuk mewujudkan hubungan industrial yang harmonis.

Manfaat dari kegiatan pengabdian kepada masyarakat ini adalah sebagai berikut :

1. Pengetahuan mengenai dasar-dasar hukum ketenagakerjaan dapat berguna sebagai landasan dalam mewujudkan hubungan industrial yang harmonis.

2. Terjadinya dialog sosial melalui lembaga kerjasama bipartit dan tripartit yang dapat bermanfaat sebagai sarana kominkasi, konsultasi, dan kerjasama antara pekerja / serikat pekerja dengan perusahaan / organisasi pengusaha.

\section{Target}

Target dari kegiatan pengabdian kepada masyarakat ini adalah sebagai berikut :

1. Meningkatnya peran serta asosiasi pengajar hukum ketenagakerjaan dalam mewujudkan hubungan industrial yang harmonis.

2. Meningkatnya pengetahuan pekerja, serikat pekerja, perusahaan, dan asosiasi pengusaha mengenai hukum ketenagakerjaan.

3. Terbentuknya dialog sosial melalui lembaga kerjasama bipartit dan lembaga kerjasama tripartit sebagai sarana komunikasi, kosultasi, dan komunikasi antara pekerja / serikat pekerja dengan perusahaan / asosiasi pengusaha di kawasan industri Karawang.

\section{Tinjauan Pustaka}

\section{Hakikat Hubungan Kerja}

Sebagai dasar untuk memahami konsep dan norma fleksibilitas hubungan kerja, maka terlebih dahulu perlu dipahami tentang hakikat hubungan kerja. Pembahasan mengenai hakikat hubungan kerja meliputi pembahsan tentang karakteristik hubungan kerja, sumber hukum otonom dan heteronom, peran kolektif serikat pekerja dalam hubungan 
industrial, dan peran afirmatif pemerintah dalam hubungan industrial.

Hubungan kerja memiliki karakteristik unik yang berbeda apabila dibandingkan dengan hubungan hukum yang lain. Karakteristik yang unik dari hubungan kerja tersebut dapat dilihat dari relasi antara subjek hukum dalam hubungan kerja yang bersifat subordinatif dan unsur-unsur dalam hubungan kerja yang membedakannya dari bentuk hubungan hukum lainnya.

\section{Karakteristik Hubungan Kerja}

Untuk mengetahui hakikat hubungan kerja, penting untuk memahami tentang karakteristik hubungan kerja. Hubungan kerja memiliki karakteristik unik yang berbeda dengan hubungan hukum pada umumnya. Hubungan kerja adalah hubungan hukum yang terjalin antara pekerja dengan pengusaha selaku pemberi kerja berdasarkan perjanjian kerja dengan unsur-unsur pembentuknya yang terdiri dari unsur pekerjaan, unsur upah, dan unsur perintah. Dari ketiga unsur hubungan kerja tersebut, unsur perintah menjadi unsur pembeda hubungan kerja dari hubungan hukum lainnya. Unsur perintah menunjukkan bahwa hubungan antara pihak pekerja dengan pihak pengusaha selaku pemberi kerja merupakan hubungan yang bersifat subordinatif.

Dengan adanya unsur di bawah perintah menjadikan pihak pekerja dalam melakukan pekerjaannya bergantung pada perintah, pengawasan, dan kendali dari pihak pengusaha selaku pemberi kerja. Meskipun pihak pekerja mempunyai keahlian atau kemampuan dalam melakukan pekerjaannya, sepanjang masih ada unsur perintah, pengawasan, dan kendali dari pengusaha selaku pemberi kerja maka hubungan kerja adalah hubungan yang bersifat subordinatif.

\section{Hubungan Kerja dalam Perspektif Para Pihak dalam Hubungan Industrial}

Hubungan kerja dapat dilihat dari 3 (tiga) perspektif yang berbeda. Ketiga perspektif tersebut mewakili kepentingan yang berbeda dari para pihak yang terlibat dalam suatu hubungan industrial. Para pihak yang memiliki perbedaan kepentingan dalam hubungan industrial tersebut adalah pekerja, pengusaha, dan pemerintah.

Perbedaan pandangan mengenai peran hukum ketenagakerjaan dalam perspektif pekerja dan pengusaha dikemukakan oleh Wheelwright sebagaimana paparan berikut ;

It is useful to consider two dramatically different views about the role of law in labour relations. In one view the law must actively protect workers from exploitation and discrimination, on the other view the goal is competitiveness facilitated by the free play of market forces means that the law should interfere as little as possible in the labour relations. ${ }^{1}$

\section{Hubungan Kerja dalam Perspektif Pekerja}

Perspektif pekerja dalam melihat hubungan kerja adalah perspektif hak asasi manusia (HAM). Dalam perspektif pekerja, pemenuhan hak asasi manusia hendaknya diberikan kepada semua pekerja tanpa membedakan pekerja dengan hubungan kerja tetap atau pekerja dengan fleksibilitas hubungan kerja berdasarkan prinsip non diskriminasi. Perlindungan hukum bagi pekerja diberikan karena keamanan dan keberlangsungan kerja menjadi terancam akibat diterapkannya fleksibilitas hubungan kerja.

Hak asasi manusia (HAM) umumnya dibagi menjadi dua kelompok yaitu Hak Sipil dan Politik (Civil and Political Rights) dan Hak Ekonomi, Sosial, dan Budaya (Economic, Social, and Cultural Rights). Hak sipil dan politik adalah hak yang berkaitan dengan kebebasan individu sebagai warga dari suatu negara yang demokratis, yang meliputi perlindungan dari tirani penguasa yang sewenang-wenang, persamaan di hadapan hukum, kebebasan untuk memilih dan dipilih dalam proses demokrasi, kebebasan berpendapat, dan seterusnya. Sedangkan hak ekonomi, sosial, dan budaya adalah hak yang berkaitan dengan hak individu dalam pemenuhan kebutuhan hidup, yang meliputi hak atas pekerjaan, hak atas pemeliharaan

1 Wheelwright, Karen, Labour Law, Butterworths, Sydney, 1999, p.7 
kesehatan, hak atas lingkungan yang sehat, hak atas jaminan sosial, dan seterusnya. Hak ekonomi, sosial, dan budaya mempunyai relevansi yang sangat besar dengan hukum ketenagakerjaan, sedangkan bentuk hak sipil dan politik yang ada relevansinya dengan hukum ketenagakerjaan diantaranya adalah hak berserikat bagi pekerja hak mogok, dan hak untuk tidak mendapatkan diskriminasi di tempat kerja.

\section{Hubungan Kerja dalam Perspektif Pengusaha}

Perspektif pengusaha dalam melihat hubungan kerja adalah perspektif ekonomi. Berdasarkan asumsi terhadap hukum ketenagakerjaan maka perspektif pengusaha dalam melihat hubungan kerja dapat dibedakan ke dalam dua kelompok yang disebut sebagai neoclassical economic dan newinstitutional economic.

Penganut paham neoclassical economic berpandangan bahwa hukum merupakan tambahan beban bagi perusahaan oleh karenanya semakin sedikit intervensi hukum dalam hubungan kerja akan semakin baik, sebaliknya penganut paham newinstitutional economic berpandangan bahwa intervensi hukum dalam hubungan kerja akan memberikan manfaat bagi perusahaan.

Perbedaan pandangan dalam melihat peran hukum ketenagakerjaan dalam hubungan kerja dikemukakan oleh Davies sebagai berikut :

Very broadly, we can devide economists into two camps: 'neoclassical' and 'newinstitutional'. They differ as to the goals they are pursuing (what their ideal labour market would look like) and as to the assumptions they use in their analysis. Those in the neoclassical camp tend to be hostile to legal intervention, and those in the newinstitutional camp who argue that labour law can benefits workers, firms, and the economy as a whole. ${ }^{2}$

Mengenai microeconomics dan macroeconomics dalam konteks hukum ketenagaakerjaan Davies mengemukakan sebagai berikut :

Microeconomics concerned with markets. The labour markets determine wages as the prices of labour, by bringing together employers as the buyers of labour, and workers as the sellers of labour. As well as having an impact on particular firms operating in particular markets, labour law also has an impact on the nations economy as a whole. Indeed when the government is contemplating changes to labour law, it is often motivated by maxroeconomics considerations. ${ }^{3}$

\section{Hubungan Kerja dalam Perspektif Pemerintah}

Perspektif pemerintah dalam melihat hubungan kerja adalah perspektif pembangunan. Dalam perspektif pemerintah, fleksibiltas hubungan kerja merupakan kebutuhan dunia usaha dalam rangka menciptakan efisiensi perusahaan akan tetapi pelaksanaannya tidak boleh melanggar peraturan perundang-undangan yang memuat norma perlindungan hukum bagi tenaga kerja.

Dalam kebijakan fleksibilitas pasar tenaga kerja, kepentingan pembangunan seringkali menjadi lebih dominan sehingga menempatkan hukum ketenagakerjaan menjadi sarana untuk mencapai tujuan efisiensi ekonomi, sebagaimana diuraikan dalam paparan berikut ini :

These 'competing conceptions' of labour law to protect the fundamental social and economic rights of the workers on the one hand, and on the other to promote economic efficiency have often ended to the benefit of the latter. It is evident that labour law has

\footnotetext{
2 A.C.L. Davies, Perspective on Labour Law, Cambridge University Press, Cambridge, 2004, p. 25

${ }^{3}$ Ibid, p. 31
} 
often been used as a tool to restrict the freedom of workers furthering managerial rights and investment interest. $^{4}$

\section{B. METODE}

\section{Jadwal Kegiatan}

Pengabdian kepada masyarakat ini dilaksanakan dengan jadwal kegiatan sebagai berikut :

Jangka Waktu : Oktober, November,

Desember 2018

Pelaksanaan Kegiatan : $\quad$ Selasa, 27

November 2018

Tempat

Singaperbangsa Jalan Ronggowaluyo

Karawang

\section{Peserta}

a. Pekerja, Serikat Pekerja di kawasan industri Karawang.

b. Perusahaan, Asosiasi Pengusaha di kawasan industri Karawang.

c. Dinas Tenaga Kerja dan Transmigrasi Karawang

\section{Metode Pelaksanaan}

Guna mencapai tujuan yang telah ditetapkan maka pelaksanaan pengabdian kepada masyarakat ini dilakukan dengan langkah-langkah sebagai berikut ;

1. Identifikasi permasalahan sebagai langkah awal untuk merumuskan materi kuliah umum, diskusi kelompok, dan pelatihan.

2. Melakukan studi lapangan ke kawasan industri Karawang sebagai tempat pelaksanaan kegiatan.

3. Penelitian pustaka sebagai kajian akademis penyusunan materi kuliah umum, diskusi kelompok, dan pelatihan.

${ }^{4}$ Surya Tjandra, Labour Law and Development in Indonesia, Leiden University Repository, Leiden, 2016, p.3
4. Penyusunan materi kuliah umum, diskusi kelompok, dan pelatihan.

\section{HASIL DAN PEMBAHASAN}

\section{Proses Kegiatan}

a. Kegiatan kuliah umum dengan materi dasar-dasar hukum ketenagakerjaan.

b. Diskusi / FGD dengan tema penyelesaian perselisihan hubungan industrial.

c. Pelatihan perancangan Perjanjian Kerja Bersama (PKB)

\section{Hasil Pelaksanaan Kegiatan}

a. Kegiatan kuliah umum dengan materi dasar-dasar hukum ketenagakerjaan berhasil dilaksanakan dengan tanggapan yang positif dari peserta yang berasal dari unsur pekerja, serikat pekerja, perusahaan, dan organisasi pengusaha dan perlu ditingkatkan kepada penguasaan materi tentang legislasi dan regulasi hukum ketenagakerjaan.

b. Diskusi / FGD mengenai penyelesaian perselisihan hubungan industrial berhasil dilaksanakan secara interaktif membahas proses perundingan bipartit, proses mediasi ketenagakerjaan, dan perlu dilanjutkan dengan materi tentang hukum acara di Pengadilan Hubungan Industrial.

c. Pelatihan perancangan Perjanjian Kerja Bersama berhasil dilaksanakan dengan materi format dan substansi Perjanjian Kerja Bersama dan perlu dilanjutkan dengan materi tentang tehnik perundingan Perjanjian Kerja Bersama.

\section{KESIMPULAN DAN SARAN}

\section{Kesimpulan}

Asosiasi Pengajar Hukum Ketenagakerjaan bekerjasama dengan Dinas Tenaga Kerja dan 
Transmigrasi Karawang telah berhasil melaksanakan kegiatan pengabdian kepada masyarakat dengan tujuan untuk mewujudkan model hubungan industrial yang harmonis di kawasan industri Karawang yang dilaksanakan pada tanggal 27 November 2019 bertempat di Aula Universitas Singaperbangsa Karawang dalam bentuk kuliah umum, focus discussion group, dan pelatihan perancangan Perjanjian Kerja Bersama (PKB) diikuti peserta dari unsur pekerja, serikat pekerja, perusahaan, dan organisasi pengusaha.

\section{Saran}

Kegiatan ini perlu ditindaklanjuti dengan peningkatan pengetahuan peserta mengenai legislasi dan regulasi di bidang ketenagakerjaan, penyelesaian perselisihan hubungan industrial melalui Pengadilan Hubungan Industrial, dan proses perundingan pembuatan Perjanjian Kerja Bersama.

\section{UCAPAN TERIMA KASIH}

Puji syukur kami panjatkan ke hadirat Allah SWT karena hanya atas pertolongan dan rahmat-Nya semata sehingga kegiatan pengabdian kepada masyarakat "Peran Asosiasi Pengajar Hukum Ketenagakerjaan Mewujudkan Model Hubungan Industrial Yang Harmonis Di Kawasan Industri Karawang" ini dapat dilaksanakan dengan baik.
Dalam kesempatan ini kami ingin menyampaikan ucapan terima kasih dan penghargaan yang tulus kepada :

1. Dinas Tenaga Kerja dan Transmigrasi Karawang.

2. Universitas Singaperbangsa Karawang.

3. Seluruh peserta dari unsur pekerja, serikat pekerja, perusahaan, dan organisasi pengusaha di kawasan industri Karawang.

Atas segala bantuan, kerjasama, dan partisipasi aktif yang diberikan selama kegiatan pengabdian kepada masyarakat ini dilaksanakan. Kami berharap kegiatan ini dapat memberikan manfaat sebesar-besarnya kepada masyarakat hubungan industrial di Karawang.

\section{REFERENSI}

1. A.C.L. Davies, Perspective on Labour Law, Cambridge University Press, Cambridge, 2004

2. Surya Tjandra, Labour Law and Development in Indonesia, Leiden University Repository, Leiden, 2016

3. Wheelwright, Karen, Labour Law, Butterworths, Sydney, 1999 